Univerzitet u Beogradu
Poljoprivredni fakultet
Institut za poljoprivrednu tehniku
Naučni časopis
POLJOPRIVREDNA TEHNIKA
Godina XLV
Broj 3, 2020.
Strane: $70-81$
Faculty of Agriculture
AaRICULTURAL ENGINEERING
Year XLV
Scientific Journal
No. 3, 2020.
Pp: $70-81$

\title{
EFFECT OF PROCESS CONDITIONS ON SANDBOX SEED OIL YIELD BY MECHANICAL EXPRESSION: A RESPONSE SURFACE APPROACH
}

\author{
David Nwabueze Onwe*1, Adeleke Isaac Bamgboye ${ }^{2}$ \\ ${ }^{I}$ University of Uyo, Faculty of Engineering, Department of Agricultural \\ and Food Engineering, P. M. B. 1017, Uyo, Nigeria. \\ ${ }^{2}$ University of Ibadan, Faculty of Technology, Department of Agricultural \\ and Environmental Engineering Ibadan, Nigeria.
}

\begin{abstract}
Cost of solvent oil extraction methods has made mechanical oil expression a desirable alternative. The effect of process variables on mechanical oil expression from sandbox seed was studied. The experimental design used for the study was a $5^{2}$ Central Composite Rotatable Design of Response Surface Methodology. Experimental factors considered were: moisture content, roasting temperature, roasting time, expression pressure and expression time. Results obtained were analyzed at $\alpha_{0.05}$. The oil yield from the sandbox seed ranged from $16.38-38.68 \%$, and was increased at processing variable ranges of $(4.0-8.0 \%)$ moisture content, $\left(80.0-90.0^{\circ} \mathrm{C}\right)$ roasting temperature, $(5.0-15.0 \%)$ roasting time, (15.0-20.0 $\mathrm{MPa})$ expression pressure and (6.0-8.0 min) extraction time. The maximum oil yield of $38.68 \%$ was obtained at the processing conditions of $6 \%$ moisture content, $85^{\circ} \mathrm{C}$ roasting temperature, $15 \mathrm{~min}$ roasting time, expression pressure of $20 \mathrm{MPa}$ and $8 \mathrm{~min}$ pressing time. Model equation relating the process variables to oil yield was developed. Coefficient of determination $\left(\mathrm{R}^{2}\right)$ relating the process was 0.8908 . The result showed that moisture content, roasting time, expression pressure and expression time had a significant influence on the sandbox oil yield. The results obtained in this study can serve for process and equipment designs for oil extraction from sandbox and other oilseeds and nuts.
\end{abstract}

Keywords: Sandbox seed, mechanically expression, oil expression, oil yield, Response surface 


\section{INTRODUCTION}

The sandbox (Hura crepitans Linn.) is a tree of the (Euphorbiaceae) family indigenous to the American continent. It is an evergreen dicotyledon perennial tree also known as possum wood and jabillo. Sandbox fruit is pumpkin-like shaped with capsules, 3-5 cm long and 5-8 cm diameter, arranged radially in carpel of 14-16 seeds.

The seeds are flattened, about $2 \mathrm{~cm}$ in diameter [9, 19]. In some places, sandbox leaves are used for medicinal purposes, but the seed has not been fully exploited and utilized [3]. However, the rich oil content of the sandbox seed has been established [13, 5]. The properties, proximate composition and chemical characterization of sandbox seed and its oil have been studied [13, 19, 10]. According to [13, 21], sandbox seed contains properties with industrial and pharmaceutical application potential and can be utilized for feed, paints, and cosmetics amongst others. However, sandbox is still regarded as an underutilized plant in Nigeria and some other parts of the world, which is planted as shade trees [1]. Previous studies on oil extraction from sandbox seeds focused mainly on solvent extraction [18, 23, 24, 19]. Oil extraction by solvent methods has become attractive for some oilseeds as it can recover up to $98 \%$ of oil [16]. However, the cost of solvent extraction has made mechanical expression one of the best alternatives for extracting oil from oil seeds and nuts. Thus, oil expression by mechanical means has been carried out on many agricultural products viz: roselle [4]; soybean [17]; neem [22]; avocado and sunflower [26]; rice bran [25]; coconut [12]; shea butter [20]; sesame [2]; Moringa [8] amongst others. The quantity and quality of extractable oil from oilseeds is first a function of the seed quality before extraction [17], then the effectiveness of the expression machine and process handling. Other factors include process parameters such as material moisture content, unit size, roasting temperature and time, expression pressure and time of extraction. These treatment variables immensely influence oil yields from oil-bearing materials by mechanical methods [15]. Thus, it is very vital that these parameters are controlled during expression for optimum oil yield [4].

Information is however scarce regarding oil extraction by mechanical means from sandbox seed. To further develop the mechanical oil expression process from sandbox seed for both commercial and industrial applications, there is need to quantify the oil yield as influenced by the processing parameters using the Response Surface Methodology (RSM). The RSM was developed as a suitable analytical instrument for optimization of process variables through the use of Central Composite Design (CCD), Box-Behnken design and D-optimal experimental designs [11]. RSM has been described as an effective method in relating the interaction of individual variables such as moisture content, roasting temperature and time, expression pressure and duration relatively to oil yield. Better than the conventional methods, the RSM utilizes minimal experimental runs to predict a combination of process variables for optimal result(s) and also develops mathematical expression(s) relating the variables and response(s) [11]. With this understanding, models can be developed from experimental procedures to predict oil yields from oil-bearing materials relatively to process variables. To effectively quantify the oil yield from sandbox seed by mechanical expression, effects of process variables such as moisture content, roasting temperature and time, expression pressure and time on oil yield were evaluated. 


\section{MATERIALS AND METHODS}

\section{Design of experimental}

The influences of process variables: moisture content, roasting temperature and time, expression pressure and time on oil yield from sandbox seed by mechanical expression were evaluated.

These selected variables are among the significant factors that influence mechanical oil expression [8]. A $5^{2}$ factorial Central Composite Rotatable Design (CCRD) of RSM experimental design developed by [7] was adopted for the experiment. The lower limit of the CCRD dropped the total number of design points to 32 runs, which consist of 16 factorial CCD, 10 axial points and 6 replications of the center points. The moisture content levels selected for this experiment was a function of the moisture content of matured sandbox seeds. The ranks of other variables selected were based on preliminary experiments carried out and previous results from research works on many oil seeds and nuts as information was not found regarding the relationship of processing factors on oil yield from sandbox seed by mechanical expression. Five levels of moisture content, $m c$ $\left[4,6,8,10\right.$ and $12 \%$ wet-basis (wb)], roasting temperature, $\gamma_{t p}\left(80,85,90,95\right.$ and $\left.100^{\circ} \mathrm{C}\right)$ and time, $\gamma_{t m}(0,5,10,15$ and $20 \mathrm{~min})$, expression pressure, $\varepsilon_{P r}(5,10,15,20$ and 25 $\mathrm{MPa})$ and time, $c x_{t m}(2,4,6,8$ and $10 \mathrm{~min})$ on the sandbox oil yield were evaluated.

\section{Development of laboratory screw press}

A laboratory screw press (Fig. 1) was developed and used for the oil expression. The five barrel press was designed for $25 \mathrm{MPa}$ maximum capacity, with a barrel capacity of $1810 \mathrm{~cm}^{3}$. The screw press pressure was calibrated as a function of the pitch diameter. Preliminary test was conducted; 500 gram sample of the ground sandbox was placed into the barrel. The press was screwed until the screw could not move any further. That point was marked on the meter rule as the $25 \mathrm{MPa}$ mark. Pitch graduation was used to mark the screw to represent 20,15, 10 and $5 \mathrm{MPa}$ respectively. The multiple barrel press was designed so as to make the work easier and faster.

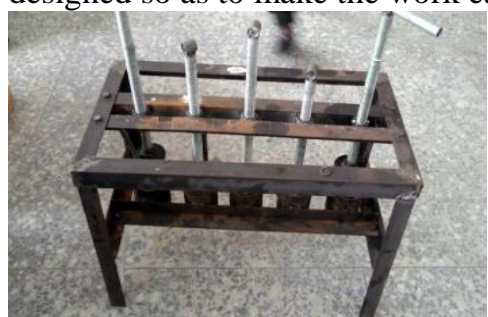

Fig. 1. Screw press

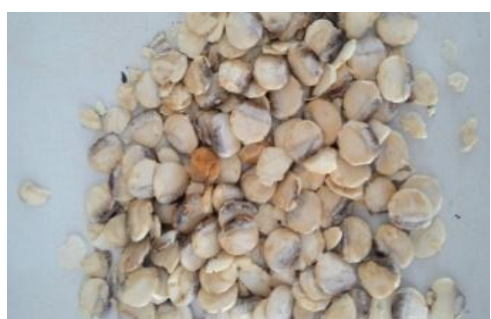

Fig. 2. Sandbox kernels

\section{Sample preparation}

Dried and mature sandbox fruits were collected and the kernels extracted (Fig. 2).

Moisture content determination

Initial moisture content of the sandbox seeds was determined by ASABE standards for oven drying method as adopted by [8] for African star apple and Moringa seeds respectively. The moisture content, $m c$ (wet-basis) was calculated from Eq. (1).

$$
\text { MC (\%w.b.) }=\frac{W_{i}-W_{f}}{W_{i}} \times 100
$$


$W_{i}=$ sample initial weight and $W_{f}=$ sample final

Samples of one $\mathrm{kg}$ each of the sandbox seeds were subjected to the required moisture content levels by Eq. (2) as adopted by [8].

$$
\mathrm{Q}=\left(\frac{100-\mathrm{S}_{\mathrm{i}}}{100-\mathrm{S}_{\mathrm{d}}}-1\right) \times \mathrm{W}_{\mathrm{s}}
$$

$Q=$ Amount of moisture to be absorbed (ml);

$S_{i}=$ sample's initial moisture content $(\% \mathrm{wb})$;

$S_{d}=$ sample's required moisture content $(\% \mathrm{wb})$;

$W_{s}=$ Sample's weight $(\mathrm{g})$

Afterwards, the samples already conditioned were wrapped in a cloth, tied in nylon bags and refrigerated at $5{ }^{\circ} \mathrm{C}$ for two days for even circulation of required moisture and transferred into a desiccator to avoid moisture migration until the commencement of the experiment.

\section{Experimental procedures}

A $500 \mathrm{~g}$ ground samples each was used for the various experiments. Samples were roasted at the stipulated temperature and time and fed into the extraction chamber (barrel) and pressed at stipulated pressures and times. Triplicate experiments were carried out. The oil was expressed into a container and left for 3 days before weighing and the oil yield was calculated using Eq. (3) as adopted by [8] for determination of percentage oil yield from Moringa.

Oil Yield $(\%)=\frac{\text { Wieght of oil expressed }}{\text { Wieght of sandbox seed sample before pressing }} \times 100$

\section{Response Surface Methodology (RSM)}

An RSM Design Expert software package (version 6.0.6) was used for the experimental design. Ranges of the experimental variables were fixed into the software to generate the combination of process factors for the experiments. The generated combinations were used for the oil expression. The oil yield got from each run was inputted as the response for that combination. These outcomes were subjected to the models of the software package which include the linear, the two factorial interactions $(2 \mathrm{FI})$, the quadratic and the cubic models respectively. The statistics in terms the probability of error value ( $\mathrm{p}$-value) and coefficient of determination $\left(\mathrm{R}^{2}\right)$ which are indicators on how well the interactions between processing variable influenced the response (oil yield) were used in selecting the best model for the process. The selected model was analyzed using Analysis Of Variance (ANOVA) in order to ascertain the level of significance and fitness of the model in interpreting the correlation between the process factors and the oil yield (response). Windows 20.0 SPSS statistical software package was used to analyze the tests of between-subjects effects of process conditions on oil yield. 


\section{RESULTS AND DISCUSSION}

The initial moisture content of the sandbox seed was obtained as $6.12 \% \mathrm{wb}$. The average oil yield at various process conditions are presented in Table 1. The relationship of the process parameters on oil yield are shown in Figs. 3-5. The oil yield from the sandbox seed ranged from $16.38-38.68 \%$.

Table 1. Oil yield from sandbox seed at various processing conditions

\begin{tabular}{|c|c|c|c|c|c|c|}
\hline Run & $\begin{array}{l}\text { Factor } 1 \\
\text { A: } m c(\%)\end{array}$ & $\begin{array}{l}\text { Factor } 2 \\
\text { B: } \gamma_{t p}(\%)\end{array}$ & $\begin{array}{l}\text { Factor } 3 \\
\text { C: } \gamma_{\text {tm }}(\min )\end{array}$ & $\begin{array}{l}\text { Factor } 4 \\
D: \varepsilon_{P r}(M P a)\end{array}$ & $\begin{array}{l}\text { Factor } 5 \\
E: \varepsilon x_{t m}(\min )\end{array}$ & $\begin{array}{l}\text { Response } \\
\text { Oil yield }(\%)\end{array}$ \\
\hline 1 & 8 & 90 & 10 & 15 & 6 & 36.14 \\
\hline 2 & 6 & 85 & 5 & 10 & 8 & 32.77 \\
\hline 3 & 6 & 95 & 15 & 10 & 8 & 35.09 \\
\hline 4 & 10 & 95 & 15 & 10 & 4 & 23.66 \\
\hline 5 & 8 & 90 & 10 & 15 & 2 & 16.38 \\
\hline 6 & 8 & 90 & 10 & 15 & 6 & 35.00 \\
\hline 7 & 10 & 85 & 15 & 20 & 4 & 24.43 \\
\hline 8 & 8 & 90 & 10 & 15 & 10 & 37.02 \\
\hline 9 & 8 & 80 & 10 & 15 & 6 & 32.66 \\
\hline 10 & 4 & 90 & 10 & 15 & 6 & 32.22 \\
\hline 11 & 8 & 90 & 10 & 15 & 6 & 36.22 \\
\hline 12 & 6 & 85 & 15 & 10 & 4 & 24.68 \\
\hline 13 & 8 & 90 & 10 & 15 & 6 & 35.00 \\
\hline 14 & 10 & 95 & 5 & 20 & 4 & 19.44 \\
\hline 15 & 10 & 85 & 5 & 20 & 8 & 25.00 \\
\hline 16 & 8 & 100 & 10 & 15 & 6 & 36.00 \\
\hline 17 & 6 & 95 & 15 & 20 & 4 & 25.00 \\
\hline 18 & 6 & 95 & 5 & 10 & 4 & 21.66 \\
\hline 19 & 8 & 90 & 20 & 15 & 6 & 34.33 \\
\hline 20 & 8 & 90 & 10 & 15 & 6 & 36.77 \\
\hline 21 & 10 & 95 & 15 & 20 & 8 & 32.88 \\
\hline 22 & 8 & 90 & 10 & 5 & 6 & 18.66 \\
\hline 23 & 8 & 90 & 10 & 25 & 6 & 30.00 \\
\hline 24 & 12 & 90 & 10 & 15 & 6 & 20.49 \\
\hline 25 & 6 & 95 & 5 & 20 & 8 & 30.66 \\
\hline 26 & 10 & 85 & 5 & 10 & 4 & 24.99 \\
\hline 27 & 8 & 90 & 10 & 15 & 6 & 35.66 \\
\hline 28 & 8 & 90 & 0 & 15 & 6 & 18.62 \\
\hline 29 & 10 & 95 & 5 & 10 & 8 & 32.54 \\
\hline 30 & 10 & 85 & 15 & 10 & 8 & 34.65 \\
\hline 31 & 6 & 85 & 15 & 20 & 8 & 38.68 \\
\hline 32 & 6 & 85 & 5 & 20 & 4 & 23.11 \\
\hline
\end{tabular}

$m c=$ moisture content of sandbox seed, $\gamma_{t p}=$ roasting temperature, $\gamma_{t m}=$ roasting time,

$\varepsilon_{P r}=$ expression pressure and $\varepsilon x_{t m}=$ extraction time

For the range of process variables considered in this study, the oil yield greatly increased at the processing variable ranges of $(4.0-8.0 \%)$ moisture content, $\left(80.0-90.0^{\circ} \mathrm{C}\right)$ roasting temperature, (5.0-15.0\%) roasting time, (15.0-20.0 MPa) expression pressure and (6.0-8.0 $\mathrm{min})$ expression time. 
The highest oil yield of $38.68 \%$ was obtained at $6 \%$ wb moisture content, $85{ }^{\circ} \mathrm{C}$ roasting temperature, $15 \mathrm{~min}$ roasting time, expression pressure of $20 \mathrm{MPa}$, at $8 \mathrm{~min}$ pressing time. Relatively to solvent extraction of oil from sandbox seed; $57.26 \%$ and $53.61 \%$ oil yield was obtained using n-hexane at reaction temperature range of (40-60 $\left.{ }^{\circ} \mathrm{C}\right),[23,19] ; 42.70 \%$ oil yield was obtained using petroleum ether at $\left(40-60{ }^{\circ} \mathrm{C}\right)$ reaction temperature [18].

Higher oil yield by solvent extraction in comparison to other extraction methods may be due to the solvent penetration capability to solubilize the lipid within the cell structure, thereby extracting as much oil as possible [6]. However a lower oil yield of 37.75 and $36.70 \%$ respectively were obtained using n-hexane $[4,24]$. The differences in oil yields occur as a result of the extraction methods used, and also, due to biological and environmental conditions [8].

Increase in moisture content from $4-8 \%$ wb showed a substantial increment in the oil yield. However, oil yield was observed to decrease at moisture content beyond $8 \%$ wb (Fig. 3). Moisture addition enhances the rate at which particles reach their saturation points during expression.

However, at excess moisture, the expression pressure is absorbed by the liquid phase without getting to the oil cells, hence, reducing oil yield [25]. Therefore, the optimum moisture content for mechanical expression of oil from sandbox seed was obtained as $8 \%$ wb beyond which there was reduction in oil yield (Fig. 3). This agrees with findings on oil seeds and nuts such as neem, avocado, and roselle amongst others as the most appropriate moisture level for screw press extraction of oil [22, 26, 4].

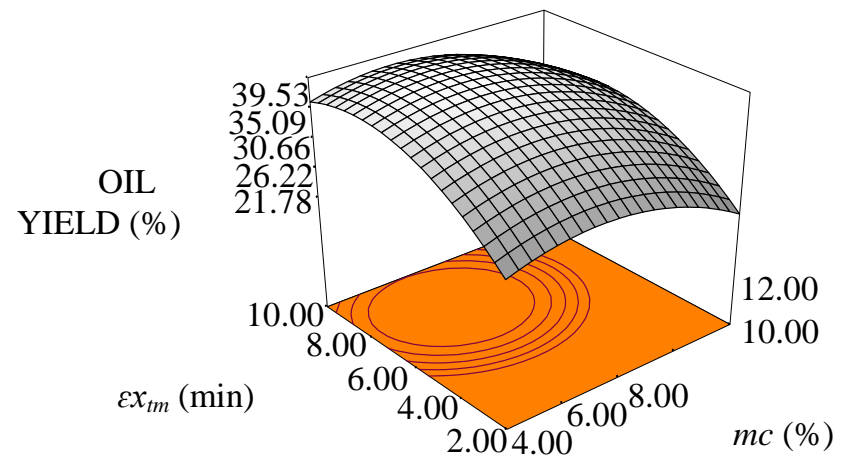

Fig.3. Extraction time and moisture content against oil yield

The oil yield increased at the roasting temperature range of $80-90{ }^{\circ} \mathrm{C}$, after which a decrease was observed at the roasting temperatures of $90-100{ }^{\circ} \mathrm{C}$ (Fig. 4). Lower heating temperatures have been suggested to be insufficient heat treatment to release sufficient oil from samples. Also, excess heat treatment hardens seeds and nuts, bringing about resistance to applied pressure during expression, thereby leading to drop in oil yield [8]. The $90{ }^{\circ} \mathrm{C}$ optimum roasting temperature obtained for sandbox seed was similar to 81.93 ${ }^{\circ} \mathrm{C}$ reported for groundnut [20], and $90{ }^{\circ} \mathrm{C}$ for African oil bean seed. 
Sandbox seed is a soft texture seed that $90{ }^{\circ} \mathrm{C}$ roasting temperature was adequate to penetrate the seed for maximum oil yield.

Finding from [4] agrees with this temperature trend obtained for sandbox seed and affirmed it to the simultaneous reduction in seed moisture, oil viscosity and protein coagulation by the addition of heat which assists oil expression process. Substantial moisture loss occurs at higher temperature, leading to hardening of oil seed sample, thus causing reduction in oil yield.

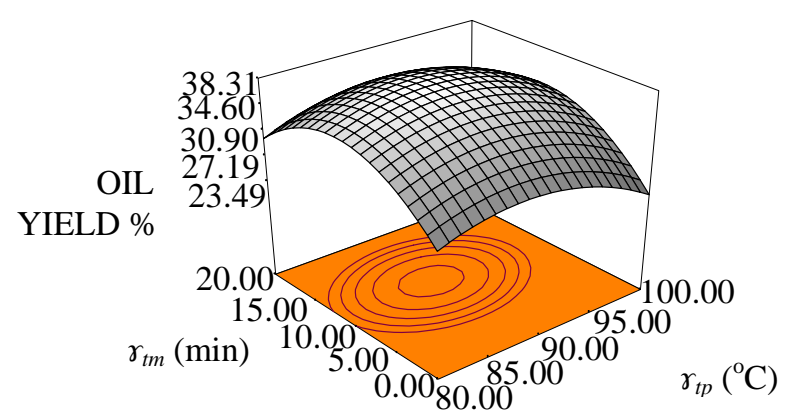

Fig. 4. Roasting time and roasting temperature against oil yield

The oil yield increased as the roasting time increased from 0-15 min. The oil yield was least at 0 minute roasting time (the un-roasted sample) and increased as roasting time increased up to 15 min beyond which a decrease was observed (Fig. 5). The oil yield was lowest for the unroasted samples, indicating the importance of heat treatment on oilseeds before oil extraction. Also, extended heating beyond 15 min roasting period decreased the oil yield. Flowability of oil varies kinematic viscosity inversely. Therefore, the decrease in kinematic viscosity as heating temperature increases enhances the release of oil [14].

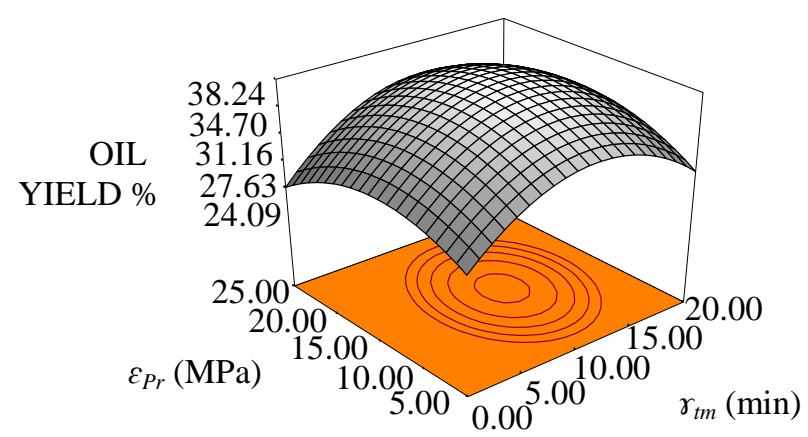

Fig. 5. Expression pressure and roasting time against oil yield

For oilseeds, heat treatment at lower temperatures required more time for moisture alteration which causes the collapse of oil capillaries, coalescence of protein and increase in oil fluidity, whereas, heat treatment at higher temperature takes shorter time to achieve same [8]. 
The highest oil yield for the sandbox seed was obtained when seed samples were roasted at $85{ }^{\circ} \mathrm{C}$ for $15 \mathrm{~min}$ (Figs. 3, 5). Similar finding was reported for sesame [2] amongst others.

Oil yield greatly increased at expression pressure of $5 \mathrm{MPa}$ up to $20 \mathrm{MPa}$. There was however a decline in oil yield as the expression pressure increased to $25 \mathrm{MPa}$ (Fig. 5). This may be related to the crushing of oil bearing pockets of the sandbox which sealed off some inter-cell spaces at increased pressure. Also, the mash formed a slurry paste which blocked the perforated oil holes on the expression machine while some flowed above the pressing base at pressure above $20 \mathrm{MPa}$. As observed by [4], increase in pressure during oil expression increases pressure on the seed cell wall, thereby rupturing them in the process to release their contents. However, continuous increase in pressure on oil seeds during expression continually compress, disrupt and may ultimately close the oil bearing vessels [27]. The observation on sandbox seed is in tandem with the findings for rice bran, melon, roselle, soybean [25, 2, 4, 17] amongst others.

There was increased oil yield as expression time increased from 2 min up to $8 \mathrm{~min}$ and decreased at expression time beyond $8 \mathrm{~min}$ (Fig. 3). Similar observation was reported for soybeans [17].

Table 2. Model Comparison

\begin{tabular}{|l|c|c|l|l|}
\hline & \multicolumn{4}{|c|}{ Models } \\
\hline Statistics & Linear & $2 F I$ & Quadratic & Cubic \\
\hline Standard deviation & 4.84 & 5.86 & 3.72 & 2.21 \\
\hline$R^{2}$ & 0.5623 & 0.6053 & 0.8907 & 0.9789 \\
\hline Mean & 29.39 & 29.39 & 29.39 & 29.39 \\
\hline Adjusted $R^{2}$ & 0.4781 & 0.2353 & 0.6921 & 0.8909 \\
\hline Coefficient of Variation & 16.47 & 19.93 & 12.65 & 7.53 \\
\hline Predicted $R^{2}$ & 0.3910 & -2.1284 & -1.8079 & -19.9477 \\
\hline PRESS & 847.71 & 4352.06 & 3906.19 & 29140.84 \\
\hline Adequate Precision & 9.272 & 5.449 & 7.280 & 10.349 \\
\hline
\end{tabular}

$F I=$ Factorial Interaction,

PRESS $=$ Predicted Sum of Square.

The equation predicting oil yield from sandbox seed and the processing parameters is as shown in (Eq. 5).

$\mathrm{OY}=35.35-1.5 m c-0.03 \gamma_{t p}+2.5 \gamma_{t m}+0.49 \varepsilon_{P r}+4.8 \varepsilon x_{t m}-1.91 m c^{2}+$

$+0.086 \gamma_{t p}{ }^{2}-2.41 \varepsilon_{P r}^{2}-1.83 \varepsilon x_{t m}^{2}+0.39 m c \gamma_{t p}-0.098 m c \gamma_{t m}-1.09 m c \varepsilon_{P r}-$

$-.64 m c \varepsilon x_{t m}-0.27 \gamma_{t p} \gamma_{t m}+0.058 \gamma_{t p} \varepsilon_{P}+0.47 \gamma_{t p} \varepsilon x_{t m}+1.04 \gamma_{t m} \varepsilon_{P r}+0.74 \gamma_{t m} \varepsilon x_{t m}-0.30 \varepsilon_{P r} \varepsilon x_{t m}$

$O Y=$ Oil Yield $(\%)$,

$m c=$ moisture content of sandbox seed, $\gamma_{t p}=$ roasting temperature,

$\gamma_{t m}=$ roasting time, $\varepsilon_{P_{r}}=$ expression pressure and $c x_{t m}=$ extraction time

The corresponding statistical parameters of Eq. 5 are as shown in the Quadratic column of (Tab. 2). The positive and negatives signs in (Eq. 5) denote proportional and inverse relationship respectively between the succeeding quantity and the oil yield. 
Values in column "Prob > F" in (Tab. 3) with of less than 0.05 represents significant model parameters; in this case $\gamma_{t m}, c x_{t m}, m c^{2}, \gamma_{t m}{ }^{2}, \varepsilon_{P r}{ }^{2}$, and $\varepsilon x_{t m}{ }^{2}$.

Table 3. ANOVA for Response Surface Quadratic Model of the Oil Extraction

\begin{tabular}{|c|c|c|c|c|l|}
\hline Source & Sum of squares & $D F$ & Mean square & F value & Prob $>F$ \\
\hline Model & 1241.52 & 20 & 62.08 & 4.49 & $0.0069^{s}$ \\
\hline$m c$ & 58.56 & 1 & 58.56 & 4.23 & 0.0642 \\
\hline$\gamma_{t p}$ & 0.022 & 1 & 0.022 & 0.0016 & 0.9688 \\
\hline$\gamma_{t m}$ & 151.76 & 1 & 151.76 & 10.97 & $0.0069^{s}$ \\
\hline$\varepsilon_{p r}$ & 5.82 & 1 & 5.82 & 0.42 & 0.5299 \\
\hline$\varepsilon_{t m}$ & 568.13 & 1 & 568.13 & 41.06 & $0.0001^{s}$ \\
\hline$m c^{2}$ & 106.76 & 1 & 106.76 & 7.47 & $0.0180^{s}$ \\
\hline$\gamma_{t m}{ }^{2}$ & 103.43 & 1 & 103.43 & 7.47 & $0.0194^{s}$ \\
\hline$\varepsilon_{p r}{ }^{2}$ & 171.01 & 1 & 171.01 & 12.36 & $0.0048^{s}$ \\
\hline$\varepsilon_{t m}{ }^{2}$ & 98.39 & 1 & 98.39 & 7.11 & $0.0219^{s}$ \\
\hline Lackidue offit & 152.21 & 11 & 13.84 & & \\
\hline Pure Error & 149.68 & 6 & 24.95 & 49.25 & $0.0003^{s}$ \\
\hline Cor Total & 2.53 & 5 & 0.51 & & \\
\hline
\end{tabular}

With a high coefficient of determination $\left(\mathrm{R}^{2}=0.8908\right)(\mathrm{Tab} .2)$ and very low probability value of $(<0.0001)$ as shown in Table 4 , the model was concluded to be significant. The 0.89 value of the $\mathrm{R}^{2}$ indicates high correlation between the process variables and sandbox oil yield. This infers $89.08 \%$ assurance of the model to explain $89.08 \%$ all the inconsistency relating the response.

Table 4. Test of between-subjects effect of process conditions on oil yield from sandbox seed

\begin{tabular}{|l|c|c|c|l|}
\hline \multicolumn{1}{|c|}{ Source } & $d f$ & Mean Square & $F$ & \multicolumn{1}{|c|}{ Significance } \\
\hline Corrected Model & 27 & 51.439 & 86.003 & $0.0001^{s}$ \\
\hline Intercept & 1 & 10656.051 & 17816.504 & $0.0001^{s}$ \\
\hline$m c$ & 3 & 67.567 & 112.970 & $0.0001^{s}$ \\
\hline$\gamma_{t p}$ & 2 & 4.189 & 7.004 & 0.049 \\
\hline$\gamma_{t m}$ & 2 & 122.883 & 205.456 & $0.0001^{s}$ \\
\hline$\varepsilon_{P r}$ & 2 & 124.977 & 208.957 & $0.0001^{s}$ \\
\hline$\varepsilon_{t m}$ & 2 & 164.746 & 275.449 & $0.0001^{s}$ \\
\hline Error & 4 & 0.598 & & \\
\hline Total & 32 & & & \\
\hline Corrected Total & 31 & & & \\
\hline
\end{tabular}

The quadratic model showed a significant relationship between the oil yield and all processing parameters except roasting temperature. This means that any value of the roasting temperature range selected can be suitable during oil expression from sandbox seeds. The Model's F-value of 4.49 (Table 3) is an indication that the model successfully interpreted the interactions among the process factors and oil yield. 
The quadratic relationship indicates that there exist optimum values of the process parameters considered above which oil yield begins to drop. This conforms to findings by [4] for mechanical oil expression.

\section{CONCLUSIONS}

From the range of process variables evaluated in this work, sandbox oil yield greatly increased at $(4.0-8.0 \%)$ moisture content; $\left(80.0-90.0^{\circ} \mathrm{C}\right)$ roasting temperature; (5.0$15.0 \%)$ roasting time; (15.0-20.0 $\mathrm{MPa})$ expression pressure; and (6.0-8.0 min) extraction time. The oil yield ranged from $16.38-38.68 \%$. The maximum oil yield of $38.68 \%$ was obtained at the processing conditions of $6 \% \mathrm{wb}$ moisture content, $85^{\circ} \mathrm{C}$ roasting temperature, 15 min roasting time, $20 \mathrm{MPa}$ expression pressure and $8 \mathrm{~min}$ pressing time. The process variables influenced the oil yield. The coefficient of determination, $\mathrm{R}^{2}$ of 0.8908 of a mathematical model relating sandbox oil yield and process factors was an indication of excellent correlation between the independent process variable. From the levels of processing factors evaluated, the model preferred, sufficiently predicted oil yield from sandbox seed by mechanical expression.

\section{REFERENCES}

[1] Adewuyi A., Paul O., Awolade, P.O., and Oderinde R.A. 2014. Hura crepitans seed oil: an alternative feedstock for biodiesel production. Journal of Fuels, 464590 (8).

[2] Ajibola, O.O., Adetunji, S.O, and Owolarafe, O.K. 2000. Oil point pressure of sesame seed. Ife J. of Technology, 9(2), 57-62.

[3] Allen, T.F. 2000. Hura crepitan L. The Encyclopedia of Pure Material Medical. HomeopatheInternational, New Delhi, India, pp. 1-2.

[4] Bamgboye, A.I., and Adejumo, O.I. 2011. Effects of processing parameters of roselle seed on its oil yield. Intl. J of Agric \& Biol Eng, 4(1), 82-86.

[5] Basumatary, S. 2013. Non-conventional seed oils as potential feedstocks for future biodiesel industries: A Review Res. J. of Chem. Sciences, Vol. 3(5), pp. 99-103.

[6] Bockisch, M. 1998. Fats and Oils Handbook. Manuals by AOCS Press.

[7] Box, G.P.E., Hunter, W.G., Hunter, J.S., 1978. Statistics for Experiments. John Wileyand Sons Inc, New York, pp. 335-375.

[8] Fakayode, O. A. and Ajav, E. A. 2016. Process optimization of mechanical oil expression from Moringa(Moringa oleifera) seeds. Industrial Crops and Products 90, 142-151.

[9] Feldkamp, S. 2006. Modern Biology. United States: Holt, Rinehart, and Winston. p. 618.

[10] Fowomola, M. A. and Akindahunsi, A. A. 2007. Nutritional quality of sandbox tree (Hura crepitans Linn.). J. of Medicinal Food, vol. 10, no. 1, pp. 159-164.

[11] Giwa, A., Bello, A. and Giwa, S.O. 2013. Artificial Neural Network Modeling of a Reactive Distillation Process for Biodiesel Production, Intl. Journal of Sc. \& Eng. Research, 6(1): pp. 1175-1191.

[12] Hammonds, T.W., Harris, R.V., and Head, S.W. 1991. The influence of moisture content on the extraction of oil from fresh grated Coconut. Tropical Sci., 31, 73-81.

[13] Idowu, D.O., Abegunrin, T.P., Ola, F.A., Adediran, A.A., and Olaniran, J.A. 2012. Measurement of some engineering properties of sandbox seeds (Hura crepitans). Agric. and Bio. J. of North America, 3(8), 318-325. 
[14] Kagwacie, O.C., and Anozie, N.A., 1995. Effect of processing conditions on solvent extraction of oil from rubber seeds. J. Agric. Technol. 3 (1), 31-40.

[15] Khan, L.M., Hanna, M.A., 1983. Expression of oil from oilseeds - a review. J. Agric. Eng. Res. 28, 495-503.

[16] Matthäus B. 2012. Oil technology. S.K. Gupta (ed.), Tech. Innovations in Major World Oil Crops, Vol. 2.

[17] Mwithiga, G., and Moriasi, L. 2007. A study of yield characteristics during mechanical oil extraction of preheated and ground soybeans. J. of Applied Sci. Res., 3(10), 1146-1151.

[18] Nwanorh, K.O. 2015. Extraction and characterization of oil from Hura crepitans (sandbox tree). Intl. Res. J. of Edu. and Innovation (IRJEI), Vol. 1, No 5.

[19] Okolie P.N., Uaboi-Egbenni P.O., and Ajekwene A.E. 2012. Extraction and quality evaluation of sandbox tree seed (Hura crepitan). Oil World J. of Agric. Sci., 8(4), pp. 359-365.

[20] Olaniyan, A.M. and Oje, K. 2007. Development of mechanical expression rig for dry extraction of shea butter from shea kernel. J. of Food Sci. and Tech., 44(5), 465-470.

[21] Olatidoye, O.P., Adeleke, A.E. Adegbite, S.A. and Sobowale, S.S. 2010. Chemical composition and nutritional evaluation of sandbox (hura crepitan) seed flour for domestic consumption and industrial. J. Med Appl. Biosciences, Vol. 2, pp.72-83.

[22] Orhevba, B.A., Chukwu, O., Osunde, Z.D., and, Ogwuagwu, V. 2013. Influence of moisture content on the yield of mechanically expressed neem seed kernel oil. Academic Res. Intl., Vol 4; No. 5.

[23] Ottih, O.P., Aneke, N.A.G., and Ejikeme, P.C. 2015. Production and characterization of paint driers from sand box seed oil (Hura Crepitans). Intl. J. of Innovative Sci., Eng. and Tech., 2 (2).

[24] Shonekan F.O and Ajayi J.O. 2015. The biochemical analysis of Hura crepitans (Sandbox Tree) seed oil and meal. Globalacademicgroup.com, accessed January 15, 2016.

[25] Sivala, K., Bhole, N.G., Mukherjee, R.K. 1991. Effect of moisture on rice bran oilexpression. J. Agric. Eng. Res. 50, pp. 81-91.

[26] Southwell, K.H., and Harris, R.V. 1992. Extraction of oil from oilseeds using the hot water flotation method. Tropical Science, 82, pp. 251-256.

[27] Ward, J.A. 1976. Processing high oil content seeds in continuous screw press. J. of American Oil Chemist Society, 53, pp. 261-264.

\section{EFEKTI PROMENE VARIJABLI OBRADE ULJA IZ SEMENA Sendbox (Hura crepitans Linn.): MEHANIČKO IZDVAJANJE}

David Nwabueze Onwe ${ }^{1}$, Adeleke Isaac Bamgboye ${ }^{2}$

${ }^{1}$ University of Uyo, Faculty of Engineering, Department of Agricultural and Food Engineering, P. M. B. 1017, Uyo, Nigeria.

${ }^{2}$ University of Ibadan, Faculty of Technology, Department of Agricultural and Environmental Engineering Ibadan, Nigeria.

Sažetak. Troškovi metoda ekstrakcije ulja učinili su mehaničku ekspresiju ulja poželjnom alternativom. Izvršeno je ispitivanje uticaja obrade promenljivih parametara na mehaničku izdvajanje ulja semena Sendbox (Hura crepitans Linn.).

Eksperimentalni dizajn korišćen za ovu studiju ima $5^{2}$ Centralnu kompozitnu rotabilnu površinsku dizajn metodologiju . 
Eksperimentalni faktori koji su uzeti u obzir bili su: sadržaj vlage, temperatura, i vreme zagrevanja, pritisak izlaganja i vreme ekspresije. Dizajn metodologije površinske reakcije usvojen za eksperiment je $\alpha_{0.05}$.

Najveći prinos ulja semena Sendbox (Hura crepitans Linn.), povećan je, i kretao se u rasponu od 16,38 do $38,68 \%$ kod sadržaja vlage od 4,0 do $8,0 \%$; temperature zagrevanja od 80,0 do $100,0^{\circ} \mathrm{C}$; vremena zagrevanja od 5,0 do 15,0 min; pritiska izdvajanja od 15,0 do 20,0 MPa, za vreme ekstrakcije od 6.0 do 8.0 min. Maksimalni prinos ulja od $38,68 \%$ je dobijen u uslovima prerade kod $6 \%$ sadržaja vlage semena, temperature zagrevanja $85^{\circ} \mathrm{C}$, sa 15 minuta zagrevanja i ekspresijskog pritiska od 20 $\mathrm{MPa}$, i 8 minuta izdvajanja ili presovanja.

Razvijen je model jednačine koja povezuje promenljive procesa sa prinosom ulja. Koeficijent determinacije $\left(R^{2}\right)$, koji se odnosi na ovaj process, bio je 0,8908 .

Rezultati pokazuju da sadržaj vlage, vreme zagrevanja, pritisak izdvajanja i vreme ekspresije imaju značajan uticaj na prinos ulja semena Sendbox (Hura crepitans Linn.).

Rezultati dobijeni u ovoj studiji mogu poslužiti za dizajn procesa i opreme za ekstrakciju ulja iz semenki Senbox i drugih semenki ulja i orašastih plodova.

Ključne reči: Sendbox seme (Hura crepitans Linn.), prerada, ekspresija, ekstrakcija ulja.

$\begin{array}{ll}\text { Prijavljen: } & \\ \text { Submitted } & 01.05 .2020 . \\ \text { Ispravljen } & \\ \begin{array}{l}\text { Revised: } \\ \text { Prihvaćen }\end{array} & 17.09 .2020 . \\ \text { Accepted: } & 28.09 .2020 .\end{array}$

